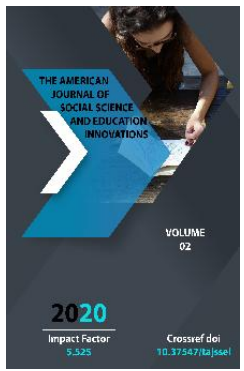

Journal Website: http://usajournalshub.c om/index,php/tajssei

Copyright: Original content from this work may be used under the terms of the creative commons attributes 4.0 licence.

\section{Teaching Loops At Second Chance Schools (SCS) Using Microworlds}

\author{
Vasileios Gougas \\ Phd Student, Faculty Of Primary And Preschool Education, St. Kliment Ohridski University Of \\ Sofia, Bulgaria
}

Lucia Malinova

Professor, Faculty Of Primary And Preschool Education, St. Kliment Ohridski University Of Sofia, Bulgaria

\title{
ABSTRACT
}

Computing Grammar is a basic part of the Second Chance School degree course. It provides agilities in order to improve the student's position in the digital world. The degree course is open for all at Second Chance Schools. The teacher according to the students' needs and beliefs provides the guidelines to be followed. They can be updated from time to time. Teaching loops is elementary in the algorithm theory. In High Schools loops and algorithms are the main field at computing lessons. The usage of Microworlds software is up to the teacher in recent years. This phenomenon is very rare at Second Chance schools and this is the first time that it is implemented. Using a poll, students' beliefs and views were stored and analyzed by the usage of statistical software in order to extract the results. Family situation, work and age constitute a strong factor of the student's agilities. Sex does not make any difference, fact that is confirmed by other researches.

\section{KEYWORDS}

Second Chance School, Adult Education, Loop, Educational Software, Education, Microworld, Life Long Learning

\section{INTRODUCTION}

Adult education is one of the most important branches of the scientific field of education. In the conceptual framework of education and continuing vocational education and training, as well as lifelong learning, the institution of Second Chance Schools in Greece was placed in line with the EU axis for the creation of a European region of lifelong learning. The EU 
White Bible in November 1995 set out five key objectives:

- $\quad$ Reducing social exclusion and racism.

- $\quad$ Students knowing at least 3 European languages.

- Private sector, society and school relationship.

- $\quad$ Encouraging citizens to acquire new knowledge.

- Individual investment in training and education

Second Chance Schools (SCS) are proposed by the EU as an institution that helps citizens of EU Member States to gain access to areas of knowledge and technology, to be encouraged to prevent exclusion (social and racial) but also to improve their working and professional position and situation.

The pilot projects of the SCSs operated in Greece in 2000, three years after their pilot implementation in 11 European countries in 1997. This was due to the fact that the funding of the SCSs. in Greece was provided by different program codes of the European Union (EU Report, 2001). In SCS the various didactic approaches are based on the concept of Literacy. For this reason in the curriculum there is the concept of Information Literacy which according to Greek Ministry of Education is the third in the hierarchy Literacy, behind the Greek Language and Numerical Literacy (Greek Law 1861 / B / 8-7-2014).

\section{LITERATURE REVIEW}

Numerous studies have been conducted in the field of Second Chance Schools (SCS) (Jimogiannis \& Gravani, (2011); Michail \& Anastasiou, (2011); Efstathiou, (2009); Koutrouba et al., (2011); Kollas \& Halkia, (2016); Katsarou \& Tsafos (2008); Rose, (2012); Ross \& Gray, (2005); Polidano et al., (2012)).
These researches try to capture and record mainly the attitudes of the students in one of the taught literatures but also the use of educational software.

The research of Polidano et al., (2012) showed that learners develop skills as citizens (better use of governance services) and that the performance of learners taking electronic exams increases compared to those taking traditional exams. The research of Ross \& Gray (2005) showed that a significant percentage of citizens have not completed their studies in high school and want a "Second Chance" in learning. Most of them want to attend a distance learning program using ICT and educational software.

Michail \& Anastasiou (2010) conducted a research aimed at investigating the causes that led students to early school leaving in the past. The lack of appropriate teaching methods such as the use of ICT and software is the second cause of abandonment in the female population and the first cause in the male population in the age group 18-35. The importance and acceptance of the use of software was captured in this research. Koutrouba et al., (2011) have shown that the use of software in the learning process has some benefits such as improving lesson planning and increasing the level of collaboration and socialization of learners.

The research of Kollas \& Halkia (2016); Katsarou \& Tsafos, (2008); Efstathiou, (2009) showed that educators with more experience who use educational software as a tool in their classroom, manage to increase the understanding of concepts related to everyday life by learners. Jimogiannis \& Gravani (2011) conducted research with the participation of trainers and students and the results of the research showed that the use of 
educational software in Computer Literacy in SCS leads to improved lesson planning by the instructor, cultivation of a better learning climate, development of digital skills of the students, cultivation of the critical thinking of the students and creation of appropriate conditions for transforming the attitudes of the students.

\section{METHODOLOGY}

The paper is related to Second Chance Schools and in particular to Computer Literacy. In the context of this literacy, the learner has the possibility of the open curriculum based on the needs and skills and desires of the group, as mentioned in the first chapter. Specifically, the purpose is to capture the change in attitudes of learners resulting from the teaching of the repetition structure with the help of a specific microcosm software, introducing them to algorithmic thinking. The process consists of three phases, but the object of the paper is only the third phase. In more detail:

In the first phase of the process, the teaching was organized in the specific school units in order to use the microcosm.

In the second phase, the teaching of the microcosm was implemented in a sufficient period of time so that the whole range of students have developed the appropriate skills and, as far as possible, have acquired a small "idea" from programming with the help of the microcosm.

In the third phase, which is the point of the thesis, the application of the microcosm by all the students was evaluated through the investigation of the perceptions, attitudes and skills acquired by the participants selfevaluatively.
The evaluation focused on four (4) research areas:

- Axis 1: The study of the formed perceptions of the students after the use of microcosm environments.

- $\quad$ Axis 2: The study of the change of the attitudes of the students towards the Information Literacy with the use of microcosm.

- $\quad$ Axis 3: The study of the Suitability Functionality of the microcosm for teaching in SCS, according to the assessments of the students.

- $\quad$ Axis 4: The study of the relationship of various demographics to the above, such as age, marital status or professional status.

The methodological framework that was used was quantitative research. Students who participated in the study program at the 1st SCS Trikala and Rhodes too.

The questionnaire was answered by 120 people. The sample consists of men and women and specifically of all intermediate age groups 19-67. The selection of this group of people was made because it is the only target group that has developed skills in the Robomind microcosm and is studying at SCSs. It appears that $39.5 \%$ of the sample is aged between 36 and $45,26.3 \%$ is aged $19-35,23.7 \%$ is aged between 46 and 54 and $10.5 \%$ is older. Also $65.8 \%$ of the sample are men while $34.2 \%$ of the sample are women.

$60.5 \%$ of the respondents before their registration in the SCS were just primary school graduates, while the remaining 39.5\% had fulfilled their obligations in at least one class of High School (A or B High School). $52.6 \%$ of the sample are unemployed (or so they state) while the rest are either 
employees (18.4\%), self-employed persons (10.5\%) or retirees (18.4\%). The great majority of the students are married (81.6\%) while $7.9 \%$ are either widowed or divorced and $10.5 \%$ are unmarried. From the above we conclude that the majority of the students are men, married, Primary School graduates, unemployed and between 36 to 54 years old.

\section{RESULTS}

The statistical processing of the results was performed with SPSS V.23 software. Cronbach's Alpha coefficient was used to calculate the internal relevance between the questionnaire questions and was found to be quite satisfactory $(a=0.802)$.

The correlations between the factors of perceived knowledge and new attitudes, appropriateness and new attitudes, perceived knowledge and appropriateness were checked.

In the case between perceived knowledge and new attitudes it was found that there is a very strong positive linear correlation between them because the value of the coefficient resulted $0.78(r=0.78, n=120, p<0.0005)$. It is something that is expected of each other.

In the case of the correlation between appropriateness and new attitudes, a strong positive correlation emerged between them, although not as strong as in the previous case, with a coefficient value of $0.55(r=0.55, n=$ $120, \mathrm{p}<0.0005)$.

A moderately positive correlation emerged between perceived improvement in knowledge and appropriateness, as the coefficient resulted in a value of 0.49 . ( $r=$ $0.49, n=120, p<0.0005)$. The subjects were divided into 4 groups:

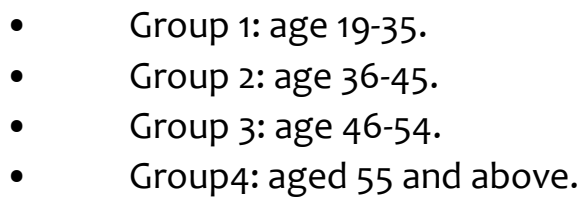

A significant difference was found between the four age groups and the variable of prior attitudes $[F(3,116)=12.5, p=.000]$ with Group $4((M)=14.33,(S D)=5.74)$ having significant differences from group $1(M=23.20, S D=$ $6.44)$, Group $2(M=23.46, S D=6.60)$ and Group $3(M=22.33, S D=8.02)$. (eta 0.204). More specifically, people over the age of 55 seem to score lower on the questions that charge in the Prior attitudes factor compared to the answers given by people in the younger age groups.

A statistically significant difference was also found between the four age groups and the variable of new attitudes $[F(3,116)=10.2, p=$ $.000]$ with Group $4(M=41.77, S D=5.78)$ having significant differences from the group $2(M=49.40, S D=5.58)$ and Group $3(M=$ 51.66, SD $=6.89)$ as well as with Group $1(M=$ $45.00, S D=9.53)$ having significant differences from Group $2(M=49.40, S D=5.58)$ and Group $3(M=51.66, S D=6.89)$. (eta 0.208).

To investigate the occupational status of the variables under study, the participants were divided into 4 groups:

- $\quad$ Group 1: Employees.
- $\quad$ Group 2: Unemployed.
- $\quad$ Group 3: Freelancers.
Group 4: Retirees.

There was a statistically significant difference between the four groups of professionals and the New Attitudes factor $[F(3,116)=6.20, p=$ .001] with Group $2(M=44.10, S D=7.88)$ having significant differences from group 1 (M $=50.42, \mathrm{SD}=4.95)$, Group $3(M=50.50, \mathrm{SD}=$ 
5.55) and Group $4(\mathrm{M}=48.88, \mathrm{SD}=8.07)$. (eta 0.204). More specifically, the unemployed answered the questions of the New Attitudes factor, scoring lower compared to the other groups of employees, retirees and freelancers.

To investigate the effect of marital status on the variables under study, the subjects were divided into 3 groups:

$$
\begin{aligned}
& -\quad \text { Group 1: Married. } \\
& \text { - } \quad \text { Group 2: Singles. } \\
& \text { Group 3: Other }
\end{aligned}
$$

There was a statistically significant difference between the three groups representing the variable marital status and the Prior Attitudes factor $[F(2,117)=3.45, p<.05]$ with Group $1(M$ $=21.96, \mathrm{SD}=7.46)$ having significant differences from Group $3(M=16.60, S D=$ 5.38). That is, the group of married people scored higher in the questions that burden the factor Prior Attitudes than the group that declared as marital status: "other".

The differences of the means of the variables were investigated between the groups of people who had completed primary school and those who had completed at least one year in high school. A statistically significant difference was found only in the variable Prior attitudes with primary school graduates $(M=$ 20.34 , SD $=7.18$ ) having on average a lower score in the Prior attitudes than those who had completed at least one additional high school year $(M=23.06, S D=7.75 ; t(118)=-$ $2.16, \mathrm{p}<.05)$. (Eta squared $=.03$ ).

\section{CONCLUSIONS}

The results of the research showed that a significant percentage of students approaching $80 \%$ improved their ICT skills after using the application. This fact fully corresponds to the findings of Polidano et al., (2013); Jimogiannis \& Gravani (2011); Rose (2012); EU Report (2001); Katsarou \& Tsafos (2008); where the use of new educational software by the students led to a significant improvement of their ICT skills.

$75 \%$ of students have transformed their attitudes after using the software, which is fully consistent with the research of Koutrouba et al., (2011); Ross \& Gray (2005); Jimogiannis \& Gravani (2011); Efstathiou (2009); where the use of appropriate educational software led learners to achieve a transformation of their attitudes to a small degree.

$85 \%$ of the students developed knowledge in relation to the previous situation, which is in line with the research findings of Koutrouba et al. (2011); Kollas \& Halkia (2016).

The largest percentage of the target group finds the application environment quite pleasant, functional, easy to use and nontedious. This finding cannot be compared with an older finding, because the microcosm is evaluated for the first time in a SCS. Of course it is relevant to the findings of Solomonidou's research (2009); Lehman (2007) referring to formal education.

A large proportion of learners responded that critical thinking and interaction with colearners were enhanced, findings that are in full agreement with the research of Rick et al., (2002); Jimogiannis \& Gravani (2011); Rose (2012); where with the use of educational software the interaction between the students increased and the students were led to a multiplication of their critical thinking.

Between perceived knowledge and new attitudes a coefficient value of 0.78 emerged 
which shows a positive strong correlation. It is something that is expected of each other. Indeed when a group transforms their attitudes then by a large percentage it has realized that a "modification" of knowledge has been made for the better as reported by Rogers (1999).

A software in order to be considered suitable for use in educational teaching, it should be characterized by an ease of use, and by its assistance in transforming attitudes and knowledge (Tselios et al., (2001)). We would expect a large positive correlation between software suitability and attitude and knowledge transformation. The research showed a positive but not so strong correlation. According to the researcher, this is due to the fact that the students themselves self-assessed the new knowledge and attitudes and not a diagnostic test. So factors such as lack of confidence and low self-esteem play an important role in the results.

\section{REFERENCES}

1. EU Report (2001) Second Chance Schools. The Results of A European Project. European Commission. Brussels 30th March 2001

2. Efstathiou I (2009) Enhancing Students Critical Awareness in a Second Chance School in Greece: Reality or Wishful Thinking? Journal of Critical Education Policy Studies, 7, 382:405

3. Greek Law, (2014), 1861 / B / 8-7-2014 [In Greek]

4. Jimogiannis A Gravani M (2011) Exploring Adult Digital Literacy Using Learners' and Educators' Perceptions and Experiences: The Case of the Second Chance Schools in Greece. Journal of Educational Technology \& Society 14 (1) 217:227
5. Katsarou E, Tsafos V (2008) Collaborative School Innovation Project As A Pivot For Teacher's Professional Development: The Case of Acharnes Second Chance School in Greece. Journal Teacher Development, 12(2), 125:138

6. Kollas S, Halkia K (2016) Second Chance Schools in Greece: A Critical Analysis of Science Teachers Views and Practises on Designing Scientific Literacy Curricula. Springer International Publishing, 289:305

7. Koutrouba K, Vamvakari M, Margara T, Anagnou E (2011) Adult Student Assesment in Second Chance Schools in Greece: Teachers Views. International Journal of Lifelong Education, 30(2), 249:270.

8. Lehman $R$ (2007) Learning Object Repositories. New Directions for Adult and Continuing Education, 113, 57:66.

9. Michail D, Anastasiou D, (2010) Gender discrimination and learning disabilities as the main reasons of dropping - out basic education. A retrospective study in the contex of Second Chance School in Greece, Lifelong Learning and Active Citizenship. Proceedings of the twelfth Conference of the Children's Identity and Citizenship in Europe Academic Network, London: January, 435:444.

10. Polidano C, Tabasso D, Tseng Y (2012) A Second Chance at Education for Early School Leavers. IZA Discussion Paper Series, 6769, 1:38

11. Rick J, Guzdial M, Carroll K, HollowayAttaway L, Walker B (2002) Collaborative learning at low cost: CoWeb use in English composition. Proceedings of Computer Support for Collaborative Learning Conference, Boulder, CO, USA: January 7-11, 435:442

12. Rogers A, (1999) Adult Education, Athens: Metaixmio. 
13. Rose M, (2012) Back to School: Why Everyone Deserves a Second Chance at Education, New York: New Press

14. Ross S, Gray V, (2005) Transitions and reengagememnt through second chance education. The Australian Education, 32, 103:140.

15. Solomonidou C (2009) Constructivist design and evaluation of interactive educational software: a research-based approach and examples, Open Education. The Journal for Open and Distance Education and Educational Technology 5(1), DOI: https://doi.org/10.12681/jode.9693.

16. Tselios N, Avouris N, Dimitracopoulou A, Daskalaki S (2001) Evaluation of Distancelearning Environments: Impact of Usability on Student Performance. International Journal of Educational Telecommunications 7(4) 355:378. 